\title{
Evidence for the Involvement in Nodulation of the Two Small Putative Regulatory Peptide-Encoding Genes MtRALFL1 and MtDVL1
}

\author{
Jean-Philippe Combier, ${ }^{1}$ Helge Küster, ${ }^{2}$ Etienne-Pascal Journet, ${ }^{1}$ Natalija Hohnjec, ${ }^{2}$ Pascal Gamas, ${ }^{1}$ \\ and Andreas Niebel ${ }^{1}$ \\ ${ }^{1}$ Laboratoire des Interactions Plantes Micro-organismes (LIPM), UMR CNRS-INRA 2594/441, F-31320 Castanet Tolosan, \\ France; ${ }^{2}$ Institute for Genome Research and Systems Biology, Center for Biotechnology (CeBiTec), Bielefeld University, \\ D-33594 Bielefeld, Germany
}

Submitted 8 February 2008. Accepted 15 April 2008.

\begin{abstract}
Nod factors are key bacterial signaling molecules regulating the symbiotic interaction between bacteria known as rhizobia and leguminous plants. Studying plant host genes whose expression is affected by Nod factors has given insights into early symbiotic signaling and development. Here, we used a double supernodulating mutant line that shows increased sensitivity to Nod factors to study the Nod factorregulated transcriptome. Using microarrays containing more than 16,000 70-mer oligonucleotide probes, we identified 643 Nod-factor-regulated genes, including 225 new Nod-factor-upregulated genes encoding many potential regulators. Among the genes found to be Nod factor upregulated, we identified and characterized MtRALFL1 and $M t D V L 1$, which code for two small putative peptide regulators of 135 and 53 amino acids, respectively. Expression analysis confirmed that these genes are upregulated during initial phases of nodulation. Overexpression of MtRALFL1 and MtDVL1 in Medicago truncatula roots resulted in a marked reduction in the number of nodules formed and in a strong increase in the number of aborted infection threads. In addition, abnormal nodule development was observed when MtRALFL1 was overexpressed. This work provides evidence for the involvement of new putative small-peptide regulators during nodulation.
\end{abstract}

Additional keywords: rhizobial infection.

Leguminous plants have the capacity to establish symbiotic interactions with specific soil bacteria that are collectively known as rhizobia. This interaction leads to the formation of new organs on the roots of host plants, called nodules, inside which atmospheric nitrogen is reduced for the benefit of the plant. This interaction is initiated by a molecular dialogue between the two symbiotic partners. Host plants excrete flavonoids that trigger bacteria to produce lipochitooligosaccharidic signals called Nod factors (NF) that are specifically perceived and transduced by the host plant (Geurts et al. 2005; Oldroyd

Corresponding author: Andreas Niebel; Telephone: +33 561285327, Fax: +33 561285061; E-mail: andreas.niebel@toulouse.inra.fr

Current address of J.-P. Combier: INSERM U563 Dept. Lipoprot. et Médiateurs Lipidiques Hopital Purpan 31024 Toulouse, France.

* The $e$-Xtra logo stands for "electronic extra" and indicates that two supplemental tables are published online. and Downie 2004; Stacey et al. 2006). Successful nodule development requires both the initiation of sequential cell divisions, first in the root pericycle and then in the inner cortical layers, leading to the formation of a nodule primordium, and the subsequent infection of the plant root by symbiotic bacteria via tubular structures called infection threads.

In the absence of rhizobia, purified NF have been shown to trigger many of the known early symbiotic responses, including specific calcium oscillations (Ehrhardt et al. 1992), and the expression of some of the so-called early nodulin genes such as ENOD2,-11,-20,-40, NIN, RIP1, and MtANN1 (D'Haeze and Holsters 2002). Depending on the species considered, purified NF can, in addition, lead to different degrees of cortical cell activation (Niwa et al. 2001; Timmers et al. 1999; Truchet et al. 1991; van Brussel et al. 1992).

The first global survey of NF-affected genes was performed by Mitra and colleagues (2004) using Affymetrix microarrays representing 9,935 Medicago truncatula tentative consensus sequences (TC). These authors demonstrated that, of the 46 genes upregulated by Sinorhizobium meliloti, 40 were also induced by NF treatment. During previous studies of the NF-regulated transcriptome, we were limited by the difficulty of detecting weakly expressed genes or genes expressed in discrete subsets of cells responding to NF treatments (Godiard et al. 2007).

In M. truncatula, supernodulating mutants belonging to two complementation groups were originally described as showing more intense or sustained root infection and nodulation upon inoculation with $S$. meliloti: the autoregulation of nodulation (AON)-defective sunn alleles (Penmetsa et al. 2003; Sagan et al. 1995, 1998; Schnabel et al. 2005) and the ethylene-insensitive mutant sickle (Oldroyd et al. 2001; Penmetsa and Cook 1997). Consequently, we decided to explore the transcriptional response to NF in $M$. truncatula using a double supernodulating mutant line to increase the detection sensitivity.

There are many reports demonstrating the importance of small regulatory peptides and secreted peptide hormones during developmental processes and defense mechanisms as shown, for example, for systemins, phytosulfokines, clavata, and clavata-like peptides (Matsubayashi and Sakagami 2006; Ryan et al. 2002). Although growing evidence suggest that the establishment of the legume-Rhizobium spp. symbiosis leading to nodule initiation and development is regulated via classical phytohormones such as ethylene, auxin, and cytokinin (Hirsch and Fang 1994; Mulder et al. 2005; Oldroyd 2007) and, more recently, jasmonic and abscisic acids (Bright et al. 2005; Liang et al. 2007; Sun et al. 2006), few reports have 
demonstrated the involvement of small peptides in the regulation of nodulation. ENOD40 plays a central role during nodulation as an active mRNA (Campalans et al. 2004; Crespi et al. 1994). However, the two small conserved peptides it encodes may also have roles during nodule development (Rohrig et al. 2002; van de Sande et al. 1996). A large family of nodule-specific cystein-rich (NCR) proteins that might act as antimicrobial defensins or diffusible signaling molecules assuring cellto-cell communication has also been described (Graham et al. 2004; Mergaert et al. 2003; Silverstein et al. 2007). Recently, Oelkers and colleagues published an interesting study of the CLE peptide family in Medicago spp. and the potential role of two of them on root meristem development; however, nodulation was not examined (Oelkers et al. 2008).

Therefore, among the large collection of new NF-activated and NF-downregulated genes we identified in this study, we were intrigued to find two genes, MtRALFL1 and MtDVL1, encoding small peptides proposed to play regulatory roles during plant development (Matsubayashi and Sakagami 2006). The rapid alkalinization factor (RALF) was first identified during purification of systemins as a 49-amino-acid (aa) peptide that causes rapid medium alkalinization but no defense responses at nanomolar concentrations in tobacco cell cultures (Pearce et al. 2001) and has been suggested to act as a regulator of root growth and development (Wu et al. 2007). The Devil (DVL) gene family, also called rotundifolia (ROT), was discovered in two different screens for fruit and leaf shape mutants within activation-tagged mutant populations of Arabidopsis thaliana (Narita et al. 2004; Wen et al. 2004) and has been proposed to control polar cell proliferation in lateral organs.

Expression analysis of MtRALFL1 and MtDVL1, presented in this study, suggest that these genes are upregulated by NF treatments and during initial phases of nodulation. In addition, overexpression studies suggest that these genes might impact on symbiotic rhizobial infection and possibly also nodule development (in the case of MtRALFL1).

\section{RESULTS}

The double supernodulating mutant sunn-2 sickle as a tool to study NF responses.

In a search for plant lines with enhanced responses to NF treatments, we decided to test supernodulating mutants. We anticipated that combining the sunn-2 (Sagan et al. 1995) and sickle (Penmetsa and Cook 1997) mutant alleles in a single plant line would result in enhanced symbiotic responses, including

Table 1. Selection of genes predicted by microarray analysis to be upregulated by Nod factor (NF) treatments ${ }^{\mathrm{a}}$

\begin{tabular}{|c|c|c|c|c|c|c|}
\hline \multirow[b]{2}{*}{ Gene category ${ }^{c}$} & \multirow[b]{2}{*}{ MtGI8 } & \multirow[b]{2}{*}{ MENS } & \multicolumn{2}{|c|}{$\mathrm{NF} / \mathrm{CF}^{\mathrm{b}}$} & \multirow[b]{2}{*}{ Gene name } & \multirow[b]{2}{*}{ Annotation } \\
\hline & & & $6 \mathrm{~h}$ & $48 \mathrm{~h}$ & & \\
\hline \multirow[t]{11}{*}{ Markers } & TC95529 & $\mathrm{MtC} 20218$ & 3.45 & 3.25 & MtAnn1 & Annexin \\
\hline & TC95776 & MtD22261 & $\ldots$ & 2.20 & MtAnn2 & Annexin \\
\hline & ТC94515 & $\mathrm{MtC} 00043$ & 1.89 & $\ldots$ & MtEnod40 & Enod40 \\
\hline & TC107261 & MtC30514 & $\ldots$ & 1.92 & MtRipl & Peroxidase \\
\hline & TC102163 & MtD27802 & $\ldots$ & 2.34 & $\ldots$ & MtN1-like \\
\hline & TC103530 & MtD03150 & $\ldots$ & 1.89 & $\ldots$ & MtN6-like protein \\
\hline & ТC96179 & MtD02963 & $\ldots$ & 5.93 & $M t N 21$ & MtN21 \\
\hline & TC109877 & MtD06265 & $\ldots$ & 2.08 & $\ldots$ & MtN21-like protein \\
\hline & TC107654 & $\mathrm{MtC} 10311$ & 2.75 & $\ldots$ & $M t N 24$ & $\mathrm{MtN} 24$ \\
\hline & TC106859 & MtC10163 & $\ldots$ & 2.20 & $\ldots$ & Nonsymbiotic leghemoglobin 1 \\
\hline & TC110699 & $\mathrm{MtC} 40073$ & $\ldots$ & 2.93 & $\ldots$ & Symbiosome membrane nodulin \\
\hline \multirow[t]{14}{*}{$\mathrm{TF}$} & TC108837 & MtD02322 & $\ldots$ & 1.92 & $\ldots$ & AP2 /ERF TF \\
\hline & TC99463 & $\mathrm{MtC} 40098$ & $\ldots$ & 1.87 & Mtern 1 & $\mathrm{AP} 2 / \mathrm{ERF} \mathrm{TF}$ \\
\hline & TC95828 & $\mathrm{MtC} 10387$ & $\ldots$ & 1.93 & $\ldots$ & $\mathrm{AP} 2 / \mathrm{ERF} \mathrm{TF}$ \\
\hline & TC102833 & MtD02676 & $\ldots$ & 1.74 & $\ldots$ & $\mathrm{AP} 2 / \mathrm{ERF} \mathrm{TF}$ \\
\hline & TC103387 & MtD04443 & 1.96 & $\ldots$ & $\ldots$ & TF B3 \\
\hline & TC97132 & MtD01395 & $\ldots$ & 1.81 & $\ldots$ & bHLH TF \\
\hline & TC95981 & $\mathrm{MtC} 10582$ & $\ldots$ & 3.80 & MtHAP2-1 & CCAAT-binding B TF \\
\hline & TC95764 & MtD05991 & $\ldots$ & 2.56 & $\ldots$ & Homeodomain leucine zipper protein \\
\hline & TC102505 & MtC50581 & 1.87 & 1.80 & $\ldots$ & HD-ZIP factor \\
\hline & AJ847976 & MtC60288 & $\ldots$ & 1.82 & $\ldots$ & HvB12D homolog \\
\hline & TC102745 & MtD00849 & $\ldots$ & 1.89 & $\ldots$ & Myb TF \\
\hline & TC108959 & MtD02812 & $\ldots$ & 2.09 & $\ldots$ & Myb (SHAQKYF class ) TF \\
\hline & TC99867 & MtD06702 & $\ldots$ & 1.84 & $\ldots$ & Myb (SHAQKYF class ) TF \\
\hline & TC96646 & MtD05611 & $\ldots$ & 1.82 & $\ldots$ & Myb (SHAQKYF class ) TF \\
\hline \multirow[t]{14}{*}{ Signal } & TC98218 & MtD05521 & $\ldots$ & 1.85 & $\ldots$ & Zn finger protein \\
\hline & TC96938 & MtD03349 & $\ldots$ & 1.78 & $\ldots$ & Leucine-rich repeat protein \\
\hline & TC98446 & MtC61331 & $\ldots$ & 2.05 & $\ldots$ & $\mathrm{Zn}$ finger protein $(\mathrm{C} 2 \mathrm{H} 2$ type $)$ \\
\hline & ТC96874 & MtC50559 & $\ldots$ & 1.96 & $\ldots$ & Putative BRI1-associated receptor kinase \\
\hline & TC108221 & MtD24088 & $\ldots$ & 1.83 & $\ldots$ & Serine/threonine-protein kinase \\
\hline & ТC95903 & MtC60470 & $\ldots$ & 2.44 & $\ldots$ & Serine/threonine protein kinase \\
\hline & TC110793 & MtC61806 & $\ldots$ & 1.99 & $\ldots$ & Putative cyclin dependent kinase \\
\hline & TC98972 & MtD06512 & 2.69 & 2.16 & MtLyk8 & LysM Receptor kinase \\
\hline & TC98204 & MtD03362 & $\ldots$ & 1.77 & $\ldots$ & LRR receptor kinase \\
\hline & ТC95733 & MtD04442 & $\ldots$ & 1.91 & MtSerk1 & BRI1-associated receptor kinase 1 \\
\hline & TC103374 & MtC62903 & $\ldots$ & 1.95 & Mtpin1 & Auxin efflux carrier \\
\hline & TC106906 & MtD00718 & $\ldots$ & 1.84 & $\ldots$ & GH3 auxin response protein \\
\hline & TC101449 & MtC61837 & $\ldots$ & 2.11 & Mtdvll & DVL protein \\
\hline & TC102073 & MtC90970 & $\ldots$ & 1.97 & Mtralf1 & Rapid alkalinization factor \\
\hline
\end{tabular}

\footnotetext{
${ }^{a}$ The MtGI8 column contains the TIGER8 gene index references and the MENS column contains the cluster references from the Medicago EST Navigation System.

${ }^{\mathrm{b}}$ Values are ratios of average expression in Nod factor (NF)-treated versus water-treated control (CF) samples; only ratios for NF-treated versus control samples greater than 1.6 with a $P$ value $<0.05$ are shown.

${ }^{\mathrm{c}}$ Markers $=$ nodulation markers, $\mathrm{TF}=$ transcription factors, and Signal $=$ signal perception and transduction.
} 
those triggered by purified NF. Therefore, we performed a cross between the sunn-2 allele TR122 and sickle and isolated from the F2 progeny a double supernodulating line, sunn-2 sickle. This double mutant showed an additive infection and nodulation phenotype (E.-P. Journet, unpublished data) similar to that described for a sunn-1 sickle double mutant (Penmetsa et al. 2003). In order to test the response of this supernodulating line to NF and validate its use for the study of the NF-regulated transcriptome, we analyzed the expression in this mutant of the wellstudied NF-responsive early nodulin gene MtENOD11 (Charron et al. 2004). The analysis of a MtENOD11-promoter: $\beta$-glucuronidase (GUS) fusion showed that this supernodulating line has an increased response to NF (Fig. 1A). Indeed, not only is MtENOD11 expression higher in the sunn-2 sickle line than in a wild-type (WT) background but, in addition, the region of the root reacting to the NF treatment is broader (Fig. 1A). This result was further confirmed by a quantitative reverse-transcriptase polymerase chain reaction (qRT-PCR) analysis. MtENOD11 induction was approximately threefold higher in the sunn-2 sickle line than in WT, both during early $(6 \mathrm{~h})$ and late $(48 \mathrm{~h})$ responses to NF (Fig. 1B). Therefore, we anticipated that the double supernodulating mutant sunn-2 sickle should be a useful tool to study the NF-regulated transcriptome.

\section{Identification of NF-responsive genes}

by microarray analysis.

Roots of young seedlings were treated either with $10^{-8} \mathrm{M}$ NF or with water as a control and harvested after 6 and $48 \mathrm{~h}$.
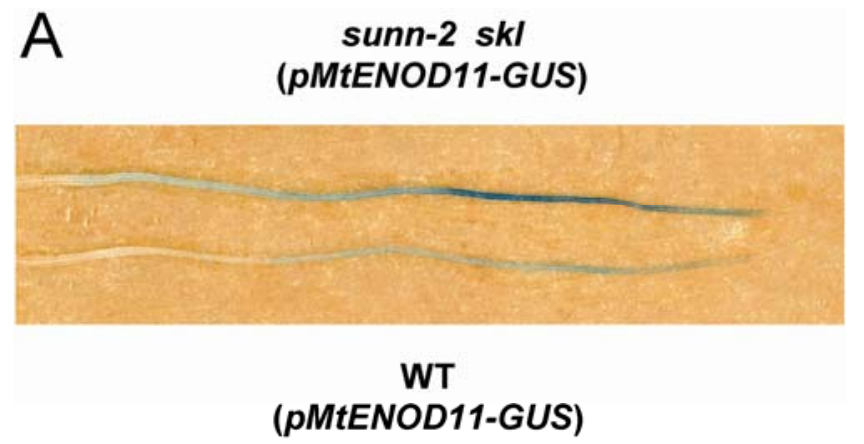

B

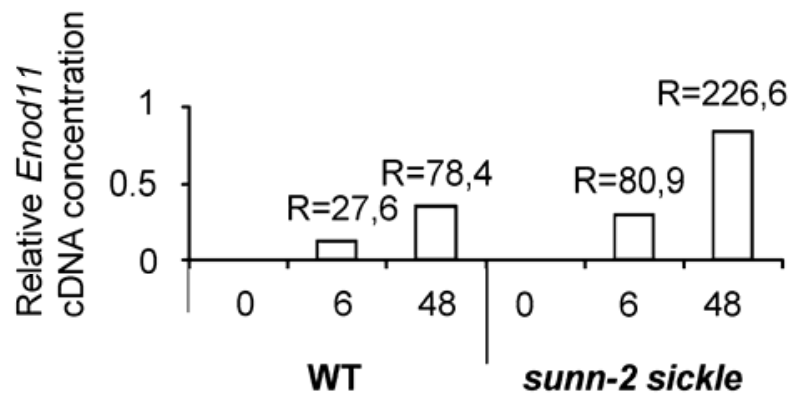

hours after treatment

Fig 1. Double supernodulating mutant sunn-2 sickle as a tool to study Nod factor (NF) responses. A, Histochemical $\beta$-glucuronidase (GUS) assay on wild-type (WT) A17 and sunn-2 sickle supernodulating lines containing the GUS gene under the control of the MtENOD11 promoter. The roots of the plantlets were treated with a $10^{-9} \mathrm{M} \mathrm{NF}$ solution for $6 \mathrm{~h}$. B, Quantitative reverse-transcriptase polymerase chain reaction analysis of the expression of MtENOD11 in roots of WT A17 and supernodulating sunn-2 sickle line in response to a $10^{-8} \mathrm{M}$ NF 6- and 48-h treatment. This figure represents one representative experiment from two biological repetitions that were qualitatively consistent. $\mathrm{R}$ stands for induction ratios between NFtreated roots versus roots before treatment (T0).
Corresponding cDNAs were then hybridized to microarrays containing 16,086 70-mer oligonucleotide probes representing more than 13,000 M. truncatula genes (Mt16kOLI1; discussed below). Using a cutoff of $P<0.05$ and a minimum ratio of 1.6 for NF-treated versus control samples, the expression of 643 genes was found to be altered by NF treatment (265 upregulated and 378 downregulated). Two populations of early- and late-induced genes, showing a limited overlap (with only 12 and 21 genes induced or repressed, respectively, at both time points), could be distinguished.

To confirm the validity of our microarray data, we first checked the expression of marker genes shown by previous studies, other than transcriptomics, to be upregulated upon NF treatment. We detected an induction for three classical NF response markers, namely MtANN1, (de Carvalho Niebel et al. 1998), RIPI (Cook et al. 1995), and MtENOD40 (Crespi et al. 1994; Fang and Hirsch 1998) (Table 1). Other markers such as MtENOD11 or MtNIN are not represented on the Mt16KOLI1 microarrays and, therefore, could not be analyzed. In addition to nodulation markers (nodulins) known to be upregulated by NF, we also identified several nodulin and nodulin-like genes described as induced during symbiosis but that had not been shown to be NF-regulated before, such as MtAnn2 (Manthey et al. 2004); MtN1-, MtN3-, MtN6-, and MtN21-like genes; MtN24 (Gamas et al. 1996); non symbiotic-leghemoglobin1; and a gene highly homologous to a soybean symbiosome membrane nodulin gene (Table 1). It is interesting to note the presence in Table 1 of MtLYK8 and MtERN1. MtLYK8 is a member of the LysM receptor kinase gene family (Arrighi et al. 2006; Limpens et al. 2003) encoding potential NF receptors such as NFP or LYK3. MtERN1 is an AP2/ERF transcription factor recently reported to be involved in NF signal transduction (Andriankaja et al. 2007; Middleton et al. 2007). These results showed that the experimental conditions used in this study were well adapted to the identification of new NF-regulated genes.

We then compared our results with those published by Mitra and associates (2004), who used Affymetrix GeneChips representing approximately $10,000 \mathrm{M}$. truncatula genes to analyze responses $24 \mathrm{~h}$ after rhizobial inoculation or NF spot application in WT M. truncatula. Despite substantial differences in biological materials, experimental conditions, and expression profiling tools (some probes being present on only one type of microarray), we found 17 of the $40(42 \%)$ NF-induced genes identified by Mitra and colleagues (Supplementary Table S2), as well as 248 additional genes. Mitra and colleagues identified only four repressed genes in their study, two of which were also identified by our approach. Consequently, nearly all of the clones we identified as repressed by NF (376 of 378) have never been described in an NF-regulation context before.

To validate our microarray data, we then performed qRTPCR analyses with 10 genes coding for potential regulators, including proteins related to hormone signaling and transcription factors. We confirmed the up- or downregulation by NF of all of these genes in the sunn-2 sickle background, which illustrates the reliability of our microarray data (Table 2). We then tested their expression pattern in WT M. truncatula and found that only half of them (5 of 10) were NF regulated as in the supernodulator sunn-2 sickle line. We propose that this difference may be due primarily to detection limits for the WT resulting from the limited number of root cells responding or from the transient expression patterns of certain genes.

\section{Identification of MtRALFL1 and MtDVL1.}

An intriguing observation was the upregulation by NF of two different genes encoding potential small regulatory peptides (Tables 1 and 2) never described so far in a symbiotic context. We hence decided to explore their possible involve- 
ment during the symbiotic interaction between $M$. truncatula and $S$. meliloti.

MtRALFL1 (TC102073, MtC90970), encodes a 135-aa peptide that shows strong homologies to members of the RALF and RALF-like (RALFL) families of peptide hormones. This family comprises 39 members in A. thaliana and 40 in $M$. truncatula showing diverse expression patterns (Olsen et al. 2002; Silverstein et al. 2007). As for other described RALF peptides, MtRALFL1 contains a predicted 27-aa-long N-terminal signal peptide, suggesting that this small peptide is secreted extracellularly (Pearce et al. 2001).

MtDVL1 (TC111142, MtC61837) is predicted to encode a small 53-aa peptide, without any clear signal peptide, homologous to the plant-specific family of potential regulatory peptides called DVL. In A. thaliana, DVL genes also belong to a large family of 21 members with partly overlapping functions (Wen et al. 2004). We identified only 10 DVL genes in the $M$. truncatula genome; however, this number is likely to increase as the genome sequence reaches completion.

\section{Expression analysis of MtRALFL1 and MtDVL1.}

An expression analysis by qRT-PCR, using gene-specific primers, revealed the symbiotic expression pattern of MtRALFL1 and MtDVL1 (Table 2; Fig. 2), and sequencing of the PCR products confirmed that no other family members were amplified.

Both genes were found to be quite strongly upregulated in NF-treated roots of the supernodulator sunn-2 sickle but not in WT plants (Table 2). MtDVL1 but not MtRALF1 was found to be transiently upregulated in WT roots inoculated by $S$. meliloti, already 1 day post inoculation (dpi), which corresponds to the so called "preinfection stage"; that is to say, prior to penetration of the bacteria in root hairs (Fig. 2A and B). This modest (1.8-fold) but reproducible upregulation was confirmed using the sunn-2 sickle line for which a much stronger (at least 6-fold) and longer induction was observed (Fig. 2D). In comparison, no significant upregulation of MtRALFL1 expression was detected in S. meliloti-inoculated WT and sunn-2 sickle roots (Fig. 2A and C). At later stages of the interaction (i.e., during nodule development), MtRALFL1 showed a weak, transient, but reproducible upregulation in young developing nodules followed by a marked downregulation (3.3-fold) during subsequent stages of nodule development (Fig. 2E). A transient upregulation was reproducibly observed for $M t D V L 1$. Indeed, corresponding transcripts were almost four times more abundant in young developing nodules than in roots (Fig. 2F). This difference then rapidly faded during nodule development, and mature (14 dpi) nodules showed the same MtDVL1 expression level as noninoculated roots.
Thus, these data suggest that the expression of both MtRALFL1 and MtDVL1 are regulated by NF treatment or during early phases of nodule development or both.

\section{Overexpression of MtRALFL1 and MtDVL1 affect rhizobial infection and nodulation.}

In A. thaliana, plants carrying loss-of-function mutations or antisense or RNAi constructs for several $D V L$ genes show no visible phenotype, probably because of functional redundancy within the large $D V L$ gene family (Narita et al. 2004; Wen et al. 2004). Wu and colleagues (2007) used RNAi to silence $R A L F$ expression in Nicotiana atenuata and observed longer roots and abnormal root hair development. However, it is not clear from these data how specific their RNAi construct is and it cannot be excluded that more than one RALF gene is silenced in this case. To investigate the possible roles of MtRALFL1 and MtDVL1 during the legume-Rhizobium interaction, we performed overexpression studies, as with AtDVL15 and AtDVL16 (Rot4) in A. thaliana leaves (Narita et al. 2004; Wen et al. 2004). Using Agrobacterium rhizogenes transformation (Boisson-Dernier et al. 2005), we generated composite plants overexpressing MtRALFLl and MtDVL1 in roots, under the control of the $35 \mathrm{~S}$ promoter. We obtained a strong increase (on average, 38- and 23-fold, respectively) in MtRALFL1- and MtDVL1-overexpressing roots (Fig. 3A) compared with empty vector controls. No obvious phenotypic effect could be observed on root morphology or root growth when comparing overexpressing and empty vector control constructs (data not shown).

However, when transgenic roots were inoculated with $S$. meliloti, a clear reduction in the number of nodules formed was observed, with an average of 3- and 3.8-fold reduction for MtRALFL1 and MtDVL1 overexpressing roots, respectively, compared with empty vector controls (Fig. 3A). In addition, in MtRALFL1 overexpressing roots, the few nodules formed had abnormal structures. These nodules remained very small, with poor rhizobial colonization (Fig. 4D), and never developed into mature nitrogen-fixing nodules. A fix ${ }^{-}$phenotype for these MtRALFL1 overexpressing composite plants was revealed by their stunted development when grown in the absence of mineral nitrogen (data not shown). In contrast, nodule development and nitrogen fixation on inoculated roots overexpressing MtDVL1 appeared normal when compared with control roots (Fig. 4E and F).

These observations led us to analyze rhizobial infection in the overexpressing transgenic roots. We discovered a strong increase in the number of abortive infections in roots overexpressing MtRALFL1 and MtDVL1 (10- and 7-fold, respectively) (Fig. $4 C)$. In addition, the infection threads that generally aborted in

Table 2. Quantitative reverse-transcriptase polymerase chain reaction (q-RT-PCR) analysis of gene expression after Nod factor (NF) treatment ${ }^{\mathrm{a}}$

\begin{tabular}{|c|c|c|c|c|c|c|}
\hline DFGI 8 & MENS ID & SS SN F6/T0 & SS SN F48/T0 & A17 F6/T0 & A17 F48/T0 & Annotation \\
\hline ТC94919 & MtC30198 & $202.35 * *$ & $53.96 * *$ & $29.27 *$ & $13.66 *$ & $\beta$-Tubulin \\
\hline ТC96874 & MtC50559 & $28.83 * *$ & $19.26 *$ & $2.09 *$ & $2.17 *$ & Putative BRI1-associated receptor kinase \\
\hline TC96646 & MtD05611 & $4.4 *$ & $8.06 *$ & 1.05 & $1.86 *$ & Myb (SHAQKYF class ) transcription factor \\
\hline TC103374 & MtC62903 & $9.24 *$ & $3.16 *$ & $1.62 *$ & 1.32 & Auxin efflux carrier \\
\hline TC102073 & MtC90970 & $4.58 * *$ & $8.8 *$ & 0.7 & 1.2 & Rapid alkalinization factor \\
\hline TC111142 & MtC61837 & $2.6 *$ & $3.8 * *$ & 0.5 & 0.8 & DVL protein \\
\hline TC102505 & MtC50581 & $3.95 *$ & $4.21 *$ & 0.78 & 1.13 & HD-ZIP transcription factor \\
\hline TC106906 & MtD00718 & $2.98 * *$ & $2.85 *$ & 0.79 & 1.12 & GH3-auxin responsive gene \\
\hline ТC97459 & MtD01753 & $1.75 * *$ & $1.72 *$ & 0.46 & 1 & EIN3 \\
\hline TC95807 & MtC60974 & 0.38 & 0.33 & $0.1 *$ & $0.23 *$ & Gibberellin-responsive gene \\
\hline
\end{tabular}

${ }^{a}$ Confirmation by qRT-PCR analysis of upregulation after 6 and $48 \mathrm{~h}$ (F6 and F48, respectively) of NF treatment, in roots of the supernodulator sunn-2 sickle line (SS SN) and wild-type Medicago truncatula (A17) for a selection of 10 potential regulator genes. Values are ratios of average expression levels for three biological replicates between NF-treated roots (F6 and F48) and roots prior to NF treatments (T0). The statistical significance of each expression ratio was calculated from the pairwise comparison between the expression levels in treated versus control samples, indicated by one or two asterisks corresponding to $P<0.05$ or 0.01 , respectively, according to the Student's $t$ test.The MtGI 8 column contains the TIGER8 gene index references and the MENS column contains the cluster references from the Medicago EST Navigation System. 
the outer root cortex led to bulbous and sac-like arrested infection pockets (Fig. 4A through C).

\section{DISCUSSION}

sunn-2 sickle as an improved tool

to study NF-regulated responses.

The first objective of this study was to broaden our knowledge of the NF-regulated transcriptome in leguminous plants. The use of the double supernodulating mutant line, sunn-2 sickle, has increased the sensitivity of this approach and provided a large collection of putative NF-regulated genes, including candidate signaling and regulatory genes, potentially involved in NF-signaling pathways.

In WT plants, AON takes place at early stages during NF signaling, before infection and possibly even before cortical cell activation (Catford et al. 2003). In the supernodulating line sunn-2 sickle, initial infection events are more frequent due to the sickle mutation (Penmetsa and Cook 1997) and AON is defective due to the sunn-2 mutation (Penmetsa et al. 2003; Schnabel et al. 2005). Overall, this leads to higher levels of infection and nodule organogenesis. Consequently, the transient accumulation of certain transcripts involved in NFsignaling is likely to be prolonged in these mutants. Such a phenomenon was already observed for MtRIP1 in both sunn-1 and sickle by Penmetsa and colleagues (2003). In this respect, the late $(48 \mathrm{~h})$ time point for our NF transcriptome analysis in sunn-2 sickle is of particular interest because it increases the likelihood of detecting low-abundance transcripts. Of course, it cannot be excluded at this stage that a certain number of the genes identified in our study are only $\mathrm{NF}$ regulated in either an ethylene perception or clavata-1-
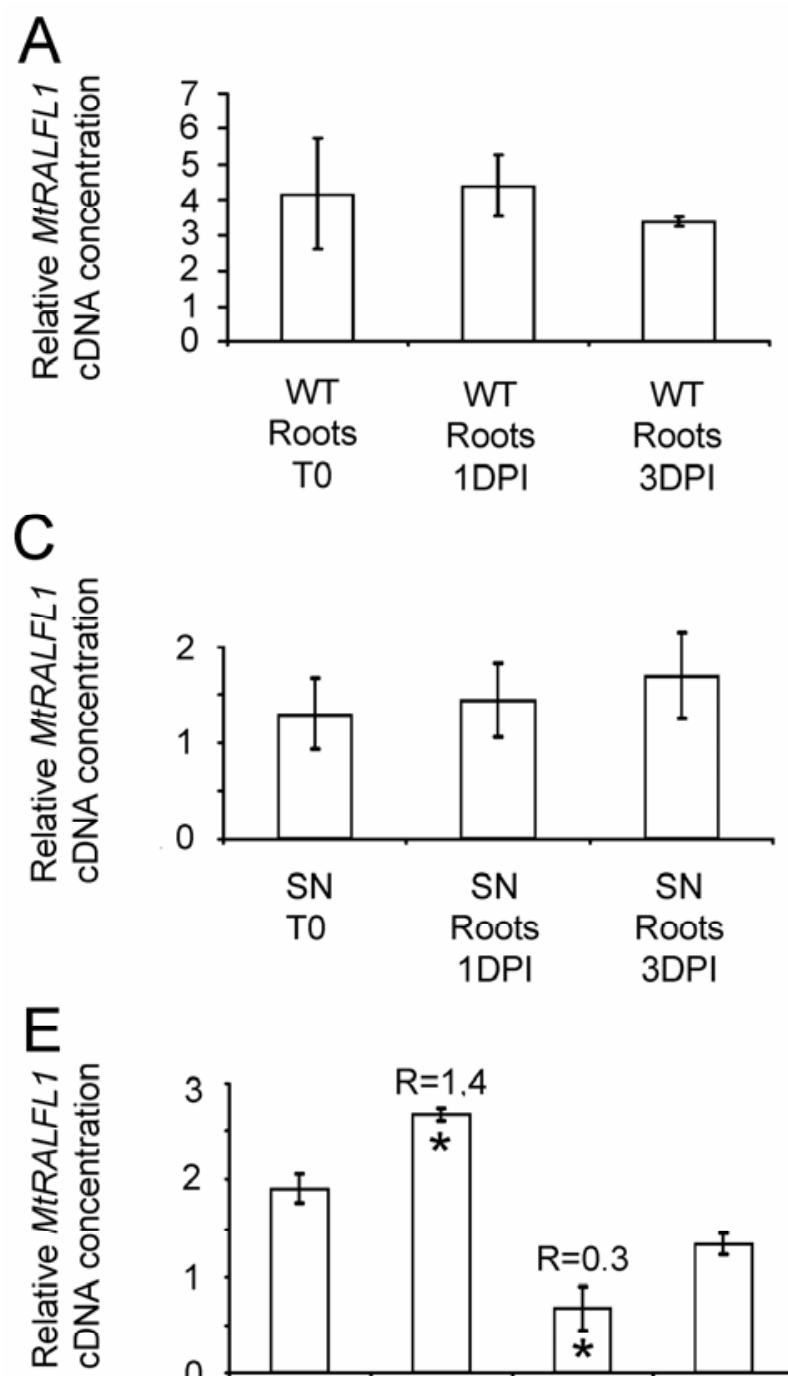
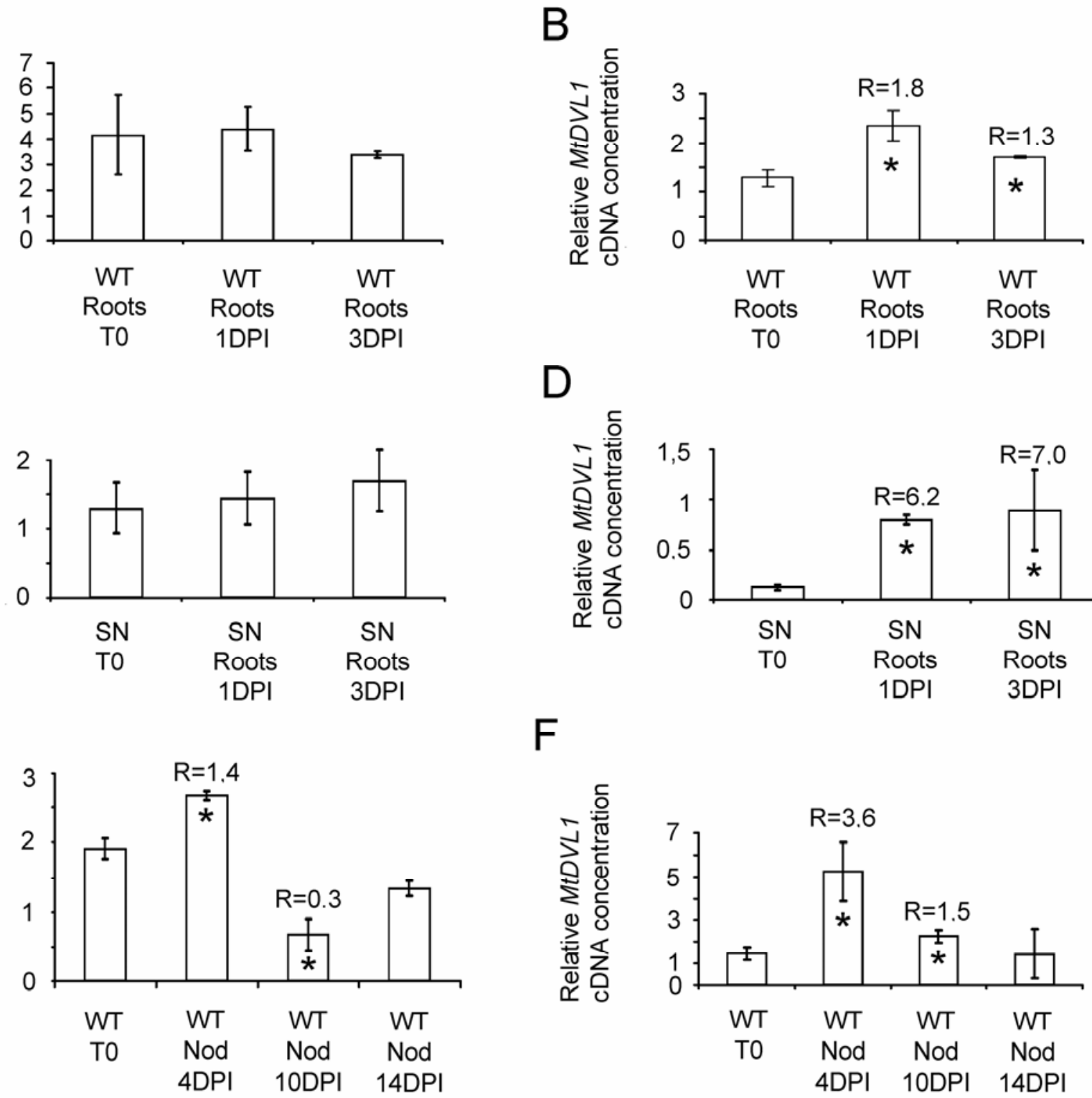

D

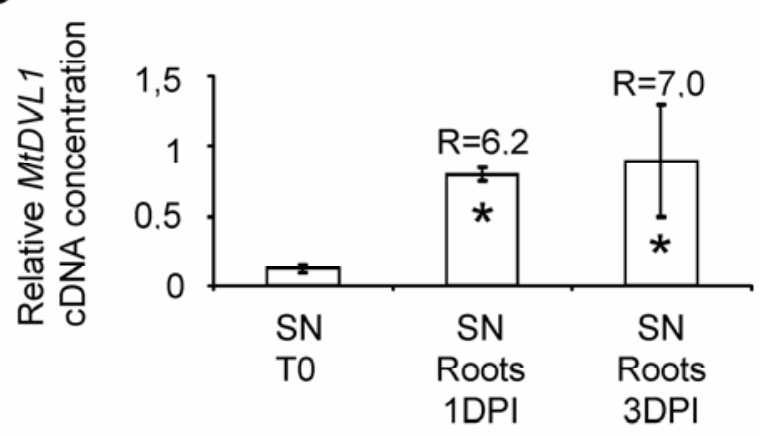

F

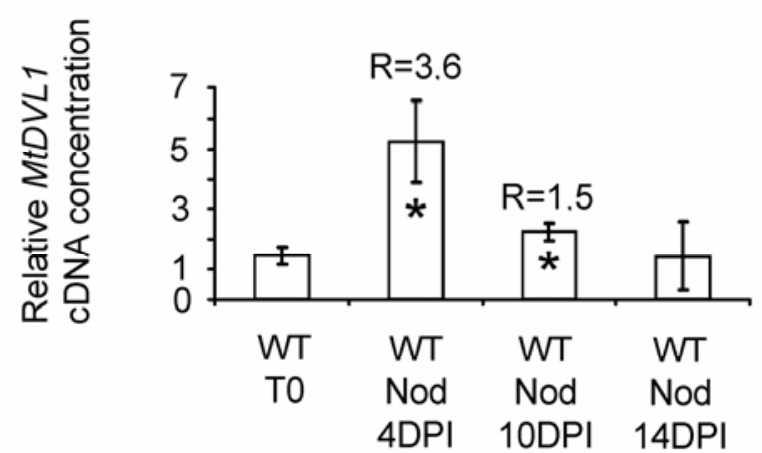

Fig. 2, Quantitative reverse-transcriptase polymerase chain reaction expression analysis of MtRALFL1 and MtDVL1 during Nod factor (NF) response and nodulation in wild-type (WT) (A17) and in the supernodulating line sunn-2 sickle. Expression analysis in response to NF of A, MtRALFL1 and B, MtDVL1 in entire WT A17 roots or isolated root hairs $(\mathrm{RH})$ treated by water $\left(\mathrm{H}_{2} \mathrm{O}\right)$ or NFs. C, E, and G, Analysis of MtRALFL1 and D, F, and $\mathbf{H}, M t D V L 1$ at different stages of the symbiotic interaction in whole root systems of $\mathbf{C}$ and $\mathbf{D}$, WT (A17) and $\mathbf{E}$ and $\mathbf{F}$, sunn-2 sickle (SN) supernodulating lines 1, 2, or 3 days post inoculation (DPI) as well as $\mathbf{G}$ and $\mathbf{H}$, in isolated nodules 4, 10, and 14 DPI. The values in all figures represent the average and standard deviation of three independent biological replicates. Numbers indicate the ratios between MtRALFL1 or MtDVL1 expression in treated roots or nodules versus control roots prior to inoculation or treatment (T0). Student's tests were used to estimate the significance of the observed differences between controls and treated samples. Asterisks are present when $P<0.05$. 
like deficient background, or both. However, these genes would not be devoid of interest because they may illustrate potential cross-talks between the NF and ethylene or AON pathways.

\section{New insights into NF-regulated genes.}

We are confident that the majority of the genes we list are truly NF regulated for several reasons. First, we have found in our list classical NF markers such as MtENOD40, MtANN1, $R I P 1$, and also a recently described element of the NF-signaling pathway called ERN1 (Andriankaja et al. 2007, Middleton et al. 2007). Second, a comparison with the only other largescale study of NF-regulated genes (Mitra et al. 2004) shows that a significant proportion (approximately 40\%) of the NFregulated genes revealed by this previous study are present in our collection. Third, we have confirmed by qRT-PCR experiments the differential expression in sunn-2 sickle for 10 selected genes, all coding for potential symbiotic regulators. This transcriptomic study has identified several other nodulin and nodulin-like genes known to be upregulated during nodulation but previously not described as being NF regulated. Importantly, among the list of 276 previously undescribed NF-repressed genes, we have identified over 50 potential regulators, including 15 transcription factors, nine kinases, four leucine-rich repeat receptor kinases, two phosphatases, two response regulator receivers, and several genes involved in auxin and gibberelin signaling (Supplementary Table S1). Although not the focus of this study, repressed regulators are likely to play equally important roles in NF signaling as upregulated regulators.

\section{The potential role of MtRALFL1 and MtDVL1 in the Rhizobium-legume symbiosis.}

Expression analyses of MtRALFL1 and MtDVL1 suggest that these genes are subject to early, transient, and localized NF-regulated expression. Overexpression experiments suggest, in addition, that both genes might have an impact on rhizobial infection during the initial progression of infection threads through the cortical root layers. Recent work questions the use of the $35 \mathrm{~S}$ promoter for overexpression studies in mature nodules, where its expression is restricted to certain tissues (Auriac and Timmers 2007). In roots, however, the $35 \mathrm{~S}$ promoter is strongly expressed in all root tissues (A. C. Timmers, unpublished results), allowing a clear conclusion about the impact of MtRALFL1 and MtDVL1 overexpression during rhizobial infection. For the majority of $M$. truncatula mutants described so far that affect rhizobial infection, such as lin (Kuppusamy et al. 2004), ern (poodle) (Middleton et al. 2007), or nfp and dmi2 (revealed by RNAi) (Arrighi et al. 2006; Limpens et al. 2005), infection thread progression is altered either in the root epidermis or later in the inner cortex or even during bacterial release in the nodule infection zone (Veereshlingam et al. 2004). Thus, a predominant blockage of infection in the outer cortical layer, as observed for both MtRALFL1 and MtDVL1, appears as an original phenotype and suggests a particular impact of these small peptides in this tissue.

In Arabidopsis thaliana, overexpression of AtDVL1-5 and AtDVL16 (ROT4) leads to pleiotropic phenotypes, including shortened stature, rounder rosette leaves, clustered inflorescences, shortened pedicles, and siliques with pronged tips (Narita et al. 2004; Wen et al. 2004). In addition, it has been shown that the reduced size of siliques and especially leaves is due to reduced cell proliferation. In the outer cortical cell layer, where most infection threads abort in roots overexpressing MtDVL1, rhizobia induce cell-cycle reactivation leading to the formation of cytoplasmic bridges, called preinfection-threads (PIT), through which infection threads then progress toward the inner cortex (Timmers et al. 1999; van Brussel et al. 1992). It would be interesting to explore whether MtDVL1 may be involved in or regulate cellular events leading to the differentiation of PIT.

Pierce and colleagues have shown that, when $10 \mu \mathrm{M}$ synthetic tomato RALF peptide is applied onto tomato and $A$. thaliana plantlets, a striking growth arrest is observed, blocking mer-
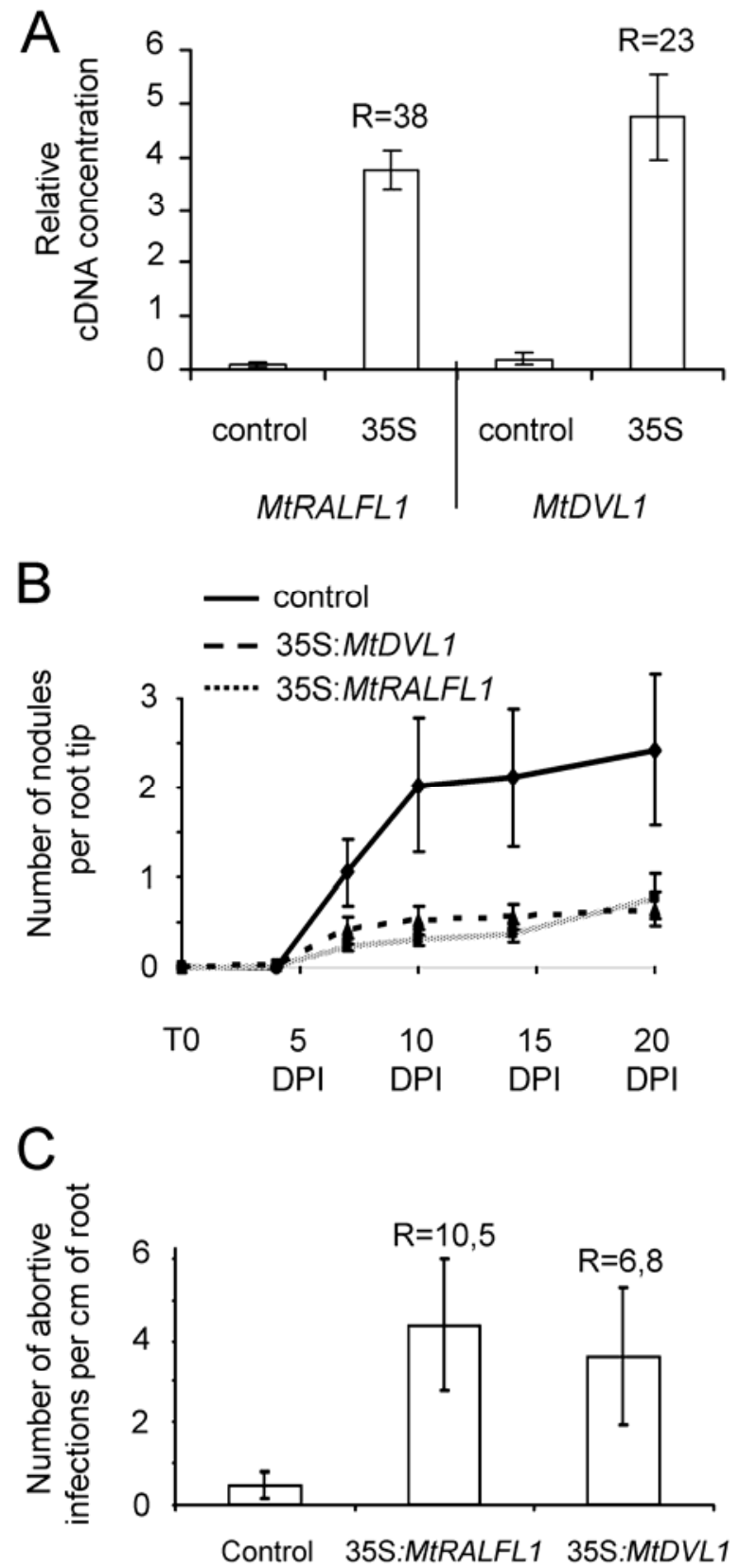

Fig. 3, Effects of MtRALFL1 and MtDVL1 overexpression on rhizobial infection and nodule formation. A, Quantitative reverse-transcriptase polymerase chain reaction analysis of the expression of $M t D V L 1$ and $M t R A L F L 1$ in roots overexpressing these genes. Data represent pools of 14 independent transgenic lines. Numbers indicate the ratios between expression levels in roots transformed with overexpression constructs $(35 \mathrm{~S})$ and empty vectors (control). B, Number of abortive infections in transgenic roots overexpressing MtRALFL1 or MtDVL1 (35S:MtRALFL1, 35S: $M t D V L 1)$ compared with empty vector transformed roots. Figures represent the average and standard deviation of infection thread counts of 17 transgenic roots revealed by a $\beta$-galactosidase assay. Bold numbers indicate the ratios between the number of abortive infections in roots transformed with overexpression constructs (35S:MtRALFL1, 35S:MtDVL1) and empty vector controls. C, Time course of nodule development (data is shown as nodules per root tip) between 0 and 20 days post inoculation (DPI) in roots transformed with overexpression constructs (35S:MtRALFL1, 35S:MtDVL1) and with an empty vector. 
istem activity and root hair formation (Pearce et al. 2001). In addition, Wu and colleagues (2007) showed that silencing $R A L F$ in $N$. alata leads to the formation of longer roots. These results suggest a negative role for some RALF peptides on root growth and development. However, overexpression of MtRALFL1 in transgenic M. truncatula roots did not lead to root growth arrest nor to any apparent effects on either root architecture or root and root-hair development. Furthermore, the marked symbiotic phenotype that we observed in the $M t R A L F L 1$ overexpressing roots and nodules suggests that different $R A L F$ gene family members could play different roles during different developmental processes (i.e., rhizobial infection or root or nodule development). The presence of a pre- dicted N-terminal signal peptide suggests that MtRALFL1 encodes a secreted peptide. Therefore, it is conceivable that MtRALFL1 is involved in cell-to-cell communication and, thus, in direct or indirect transduction of the NF signal. This hypothesis is particularly attractive in the light of a recent finding of Scheer and colleagues (2005), who identified two cell surface membrane proteins in tomato that could be part of a LeRALF receptor complex. Thus, we can speculate that overexpression of MtRALFL1 might perturb this signal transduction between cells, leading to abnormal infection and possibly defects in nodule development.

Using a transcriptome approach based on the supernodulating line sunn-2 sickle, we have identified a large collection of
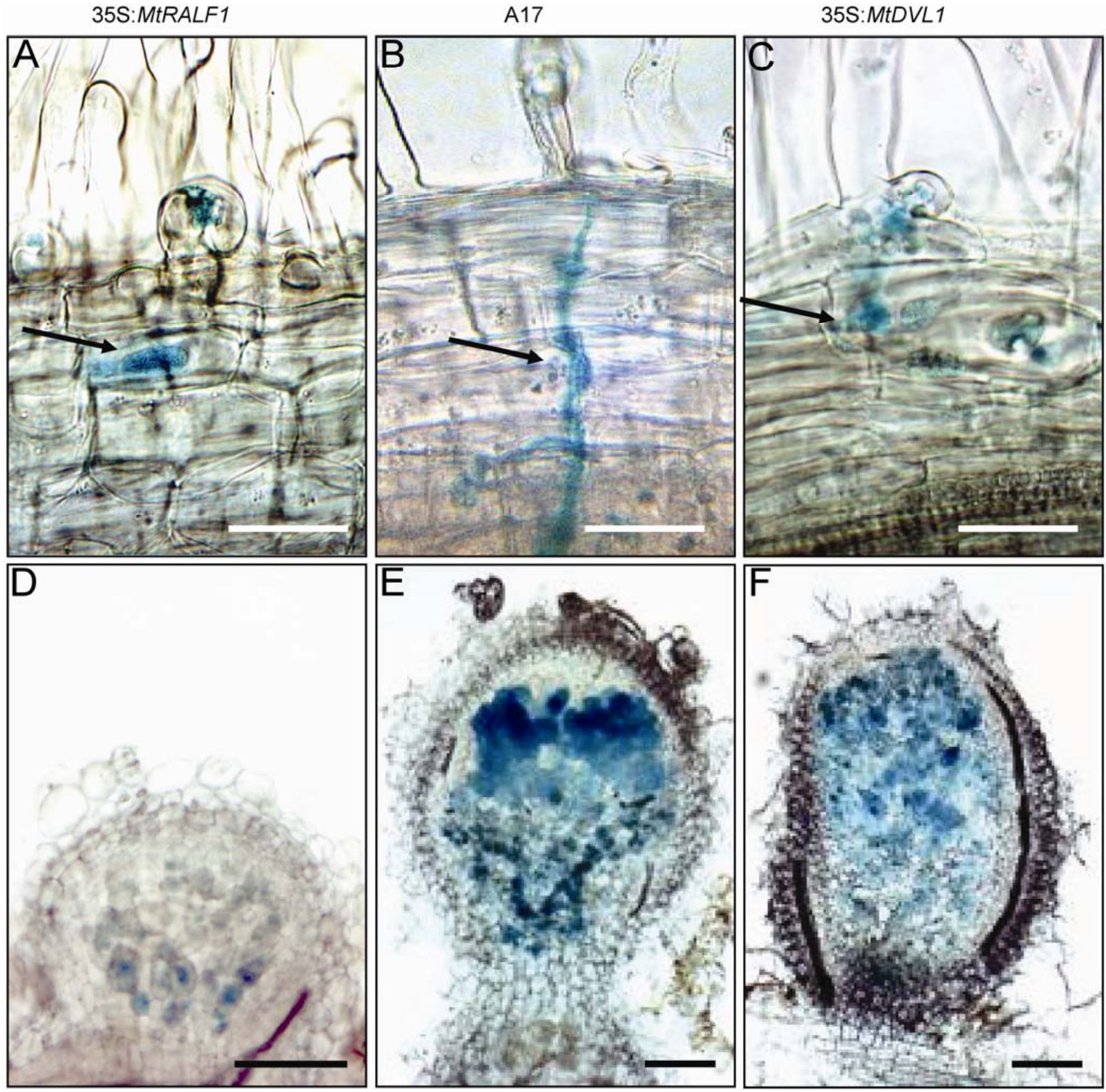

Fig. 4. Cytological analysis of the effects of MtRALFL1 and MtDVL1 overexpression on infection and nodule development. A through $\mathbf{C}$, Infection thread (IT) morphology in root hairs and outer cortex of roots transformed with $\mathbf{A}$, a MtRALFL1 overexpression construct, $\mathbf{B}$, empty vector control, and $\mathbf{C}$, a MtDVL1 overexpression construct. Arrows point to ITs in both B, a successful wild-type (WT) infection 3 days post inoculation (dpi) and roots 20 dpi showing arrested and abnormal ITs in transgenic roots overexpressing A, MtRALFL1 or C, MtDVL1. D through F, Morphology of nodules 20 dpi developing on roots transformed with $\mathbf{D}$, a MtRALFL1 overexpression construct, E, empty vector control, and $\mathbf{F}$, a $M t D V L 1$ overexpression construct. Scale bars represent $25 \mu \mathrm{m}$ (A through C) and $100 \mu \mathrm{m}$ (D through F). 
NF-responsive genes in the model legume $M$. truncatula, representing a significant contribution to the description of NF responses in legumes. Our study also suggests a role for MtDVL1 and MtRALFL1 during nodulation and, in particular, during symbiotic rhizobial infection. Thus, in addition to more classical hormones such as ethylene, auxin, or cytokinin, these small potential regulatory peptides might also be required for early steps of the symbiotic Rhizobium spp.-legume interaction.

\section{MATERIALS AND METHODS}

Cultivation of plants, treatment, and harvesting of tissues.

The double mutant line sunn-2 sickle was obtained by crossing the sunn-2 allele TR122 (Sagan et al. 1995) harboring the pMtENOD11-GUS construct to the sickle line (Penmetsa and Cook 1997). Both GUS-negative and GUS-positive plants were screened from the F2 progeny and selfed to produce homogeneous F3 populations. The double mutant character was genetically verified by test crosses to either parental single mutant.

Plant growth chamber conditions were as follows: temperature, $22^{\circ} \mathrm{C} ; 75 \%$ hygrometry, light intensity, $200 \mu \mathrm{E} \mathrm{m} \mathrm{m}^{-2} \mathrm{~s}^{-1}$; light and dark photoperiod, 16 and $8 \mathrm{~h}$, respectively. WT $M$. truncatula A17 and supernodulating sunn-2 sickle line plants were grown aeroponically during 11 days using a nitrogen-rich medium as described by Journet and associates (2001) with approximately 100 plants per caisson. Plants were then nitrogen starved for 4 days before being inoculated or NF treated. $\mathrm{NF}$ treatments were performed using a final concentration of $10^{-8} \mathrm{M}$ WT (S. meliloti) NF solution or water for the control plants. Inoculations were performed with the $S$. meliloti GMI 6526 strain carrying a constitutive hemA::lacZ fusion as described by Ardourel and associates (1994) and grown at $30^{\circ} \mathrm{C}$ in tryptone yeast medium supplemented with $6 \mathrm{mM}$ calcium chloride and tetracycline at $10 \mu \mathrm{g} \mathrm{ml}^{-1}$, as described previously (El Yahyaoui et al. 2004 ).

Entire root systems were harvested 6 and $48 \mathrm{~h}$ after NF or water control treatments and at 0,1 , and 3 dpi by $S$. meliloti. Entire nodules were dissected and harvested 4, 10, or 14 dpi. All tissues were frozen and subsequently ground in liquid nitrogen.

\section{Microarray hybridization.}

Total RNA was isolated from NF- and water-treated roots using Trizol (Invitrogen, Cergy Pontoise Cedex, France), quantified using the Nanodrop technology (Wilmington, DE, U.S.A.) and qualitatively checked using a Bioanalyser (Agilent, Santa Clara, CA, U.S.A.). Total RNA (20 $\mu \mathrm{g})$ was then used to synthesize Cy3- and Cy5-labeled cDNA targets as described by Küster and associates (2004). Mt16kOLI1 microarray hybridizations were performed using two independent biological replicates per experimental treatment. Hybridization of targets, image acquisition, and analysis of image data were performed as described previously (Hohnjec et al. 2005). Image processing data were analyzed using the EMMA 2.0 software (Dondrup et al. 2003). Lowess normalization was performed using a floor value of 20 and a Students $t$ test was applied to identify differentially expressed genes. Only those genes with a minimum expression ratio of 1.6 at $P<0.05$ were considered that, in addition, were based on a minimum of $50 \%$ of nonflagged replicate spots.

The Mt16kOLI1 microarray definition file can be viewed on the European Bioinformatics Institute (EBI) website under accession number A-MEXP-85. In short, the microarray is composed of 16,086 70-mer oligonucleotide probes representing all TC of the TIGR M. truncatula gene index, release 5.0. Each probe is represented by two replicate spots per microarray. Complete transcriptome profile datasets can be viewed at the EBI website under accession numbers E-MEXP-943.
qRT-PCR.

For real-time qRT-PCR experiments, RNA was isolated using the SV total RNA extraction kit (Promega Corp., Madison, WI, U.S.A.), and also quantified using the Nanodrop technology and quality checked using a Bioanalyser (Agilent). Total RNA (3 $\mu \mathrm{g})$ was reverse transcribed using the Superscript II enzyme from Invitrogen. Real-time PCR was then performed on a Light cycler (Roche, Mannheim, Germany) using Syber-Green and the following primers: MtDVLqF (GGAGCAAAGGGCTAGGCTAT), MtDVLqR (TGAACGGTGGACACTGCTAC), MtRALFqF (TCCAACCCAAAAACAACACA), and MtRALFqR (GGGAA GTGCAGATTGGAAGA), amplifying a 200-bp fragment between position 136 and 336 of expressed sequence tag (EST) cluster MtC61837 for MtDVL1 and a 105-bp fragment between position 10 and 115 of EST cluster MtC90970 for MtRALFL1. Specificity of amplification was then tested by sequencing. The values were normalized with an internal control, EFI- $\alpha$ : (MtGI8: TC106470 and MENS: MtD00010.1_GC), using primers EF1 $\alpha$ F: CTTTGCTTGGTGCTGTTTAGATGG and EF1 $\alpha$ R: ATTCCAAAGGCGGCTGCATA verified to be expressed at a similar level in the tested conditions. Three biological replicates were used for each sample and the data shown correspond to the mean value and standard deviation of these three repeats.

\section{Overexpression experiments.}

Overexpression of MtDVL1 and MtRALFL1 was performed by inserting a 145- and 407-bp fragment, respectively, into pPEX, a pGreen-based vector containing DsRed as a reporter gene (Combier et al. 2006) using the Xho1-Not 1 restriction sites after amplification with the following primers: MtDVL5'Xho (TCAGTCCGCTCGAGATGAAGATGGGTGC TATTGGAGG), MtDVL3'Not (AAGGAAAAAAGCGGCC GCTTACTCATGCCAACATAGAAGC), MtRALF5'Xho (TC AGTCCGCTCGAGATGTCCCAACTCAGATTCACTT), and MtRALF3'Not (AAGGAAAAAAGCGGCCGCTTAAGTGTT GATTTCTTGCGCAC).

Both constructs and empty control vectors were introduced into Agrobacterium rhizogenes Arqual strain and root transformations of $M$. truncatula were then performed as described by Boisson-Dernier and associates (2005). Transgenic plants were transferred into growth pouches 3 weeks after transformation and supplemented with caisson growth medium as described by Journet and associates (2001). Composite plants were inoculated with $S$. meliloti, 1 week after transfer.

\section{Observation and counting of infection threads.}

The presence of infecting hemA::lacZ bacteria was revealed by performing a $\beta$-galactosidase activity test using 5-bromo-4chloro-3-indolyl-beta-D-galactopyranoside (Biosynth AG, Staad, Switzerland) as described previously (Boivin et al. 1990). Infection threads were counted at $20 \mathrm{dpi}$, and those not leading to nodule development at such a late stage were counted as abortive infection threads.

\section{Histochemical GUS staining.}

GUS stainings were performed as described by Journet and associates (2001).

\section{ACKNOWLEDGMENTS}

This work was supported by the European Community FP6 Grain Legume Integrated Project (FP6-2002-FOOD-1-506223). We are grateful to F. Maillet and J. Dénarié for the generous gift of purified S. meliloti NF that made this work possible; J. Gouzy for his help in identifying MtRALFL and $M t D V L$ genes in the $M$. truncatula genome sequence; F. de CarvalhoNiebel, C. Gough, and D. Barker for fruitful discussions and critical reading of the manuscript; and J.-M. Prosperi for providing us with M. truncatula A17 seed. 


\section{LITERATURE CITED}

Andriankaja, A., Boisson-Dernier, A., Frances, L., Sauviac, L., Jauneau, A., Barker, D. G., and de Carvalho-Niebel, F. 2007. AP2-ERF transcription factors mediate Nod factor-dependent MtENOD11 activation in root hairs via a novel cis-regulatory motif. Plant Cell 19:2866-2885.

Ardourel, M., Demont, N., Debelle, F., Maillet, F., de Billy, F., Prome, J.C., Denarie, J., and Truchet, G. 1994. Rhizobium meliloti lipooligosaccharide nodulation factors: Different structural requirements for bacterial entry into target root hair cells and induction of plant symbiotic developmental responses. Plant Cell 6:1357-1374.

Arrighi, J. F., Barre, A., Ben Amor, B., Bersoult, A., Soriano L. C., Mirabella, R., de Carvalho-Niebel, F., Journet, E. P., Gherardi, M. Huguet, T., Geurts, R., Denarie, J., Rouge, P., and Gough, C. 2006. The Medicago truncatula LysM-receptor kinase gene family includes NFP and new nodule-expressed genes. Plant Physiol. 142:265-279.

Auriac, M. C., and Timmers, A. C. 2007. Nodulation studies in the model legume Medicago truncatula: Advantages of using the constitutive EF1alpha promoter and limitations in detecting fluorescent reporter proteins in nodule tissues. Mol. Plant-Microbe Interact. 20:1040-1047.

Boisson-Dernier, A., Andriankaja, A., Chabaud, M., Niebel, A., Journet, E. P., Barker, D. G., and de Carvalho-Niebel, F. 2005. MtENOD11 gene activation during rhizobial infection and mycorrhizal arbuscule development requires a common AT-rich-containing regulatory sequence. Mol. Plant-Microbe Interact. 18:1269-1276.

Boivin, C., Camut, S., Malpica, C. A., Truchet, G., and Rosenberg, C. 1990. Rhizobium meliloti genes encoding catabolism of trigonelline are induced under symbiotic conditions. Plant Cell 2:1157-1170.

Bright, L. J., Liang, Y., Mitchell, D. M., and Harris, J. M. 2005. The LATD gene of Medicago truncatula is required for both nodule and root development. Mol. Plant-Microbe Interact. 18:521-532.

Campalans, A., Kondorosi, A., and Crespi, M. 2004. Enod40, a short open reading frame-containing $\mathrm{mRNA}$, induces cytoplasmic localization of a nuclear RNA binding protein in Medicago truncatula. Plant Cell 16:1047-1059.

Catford, J. G., Staehelin, C., Lerat, S., Piche, Y., and Vierheilig, H. 2003. Suppression of arbuscular mycorrhizal colonization and nodulation in split-root systems of alfalfa after pre-inoculation and treatment with Nod factors. J. Exp. Bot. 54:1481-1487.

Charron, D., Pingret, J.-L., Chabaud, M., Journet, E. P., and Barker, D. G. 2004. Pharmacological evidence that multiple phospholipid signaling pathways link Rhizobium nodulation factor perception in Medicago truncatula root hairs to intracellular responses, including $\mathrm{Ca} 2+$ spiking and specific ENOD gene expression. Plant Physiol. 136:3582-3593.

Combier, J.-P., Frugier, F., de Billy, F., Boualem, A., El-Yahyaoui, F., Moreau, S., Vernié, T., Ott, T., Gamas, P., Crespi, M., and Niebel, A. 2006. MtHAP2-1 is a key transcriptional regulator of symbiotic nodule development regulated by microRNA169 in Medicago truncatula. Genes Dev. 20:3084-3088.

Cook, D., Dreyer, D., Bonnet, D., Howell, M., Nony, E., and VandenBosch, K. 1995. Transient induction of a peroxidase gene in Medicago truncatula precedes infection by Rhizobium meliloti. Plant Cell 7:43-55.

Crespi, M. D., Jurkevitch, E., Poiret, M., d'Aubenton-Carafa, Y., Petrovics, G., Kondorosi, E., and Kondorosi, A. 1994. enod40, a gene expressed during nodule organogenesis, codes for a non-translatable RNA involved in plant growth. EMBO (Eur. Mol. Biol. Organ.) J. 13:5099-5112.

de Carvalho Niebel, F., Lescure, N., Cullimore, J. V., and Gamas, P. 1998. The Medicago truncatula MtAnn1 gene encoding an annexin is induced by Nod factors and during the symbiotic interaction with Rhizobium meliloti. Mol. Plant-Microbe Interact. 11:504-513.

D'Haeze, W., and Holsters, M. 2002. Nod factor structures, responses, and perception during initiation of nodule development. Glycobiology 12:79R-105R

Dondrup, M., Goesmann, A., Bartels, D., Kalinowski, J., Krause, L., Linke, B., Rupp, O., Sczyrba, A., Pühler, A., and Meyer, F. 2003. EMMA: A platform for consistent storage and efficient analysis of microarray data. J. Biotechnol. 106:135-146.

Ehrhardt, D. W., Atkinson, E. M., and Long, S. R. 1992. Depolarization of alfalfa root hair membrane potential by Rhizobium meliloti Nod factors. Science 256:998-1000.

El Yahyaoui, F., Küster, H., Ben Amor, B., Hohnjec, N., Pühler, A., Becker, A., Gouzy, J., Vernié, T., Gough, C., Niebel, A., Godiard, L., and Gamas, P. 2004. Expression profiling in Medicago truncatula identifies more than 750 genes differentially expressed during nodulation, including many potential regulators of the symbiotic program. Plant Physiol. 136:3559-3576.

Fang, Y., and Hirsch, A. M. 1998. Studying early nodulin gene ENOD40 expression and induction by nodulation factor and cytokinin in transgenic alfalfa. Plant Physiol. 116:53-68.

Gamas, P., de Carvalho Niebel, F., Lescure, N., and Cullimore, J. V. 1996.
Use of a subtractive hybridization approach to identify new Medicago truncatula genes induced during root nodule development. Mol. PlantMicrobe Interact. 9:233-242.

Geurts, R., Fedorova, E., and Bisseling, T. 2005. Nod factor signaling genes and their function in the early stages of Rhizobium infection. Curr. Opin. Plant Biol. 8:346-352.

Godiard, L., Niebel, A., Micheli, F., Gouzy, J., Ott, T., and Gamas, P. 2007. Identification of new potential regulators of the Medicago truncatula-Sinorhizobium meliloti symbiosis using a large-scale suppression subtractive hybridization approach. Mol. Plant-Microbe Interact. 20:321-332.

Graham, M. A., Silverstein, K. A., Cannon, S. B., and VandenBosch, K. A. 2004. Computational identification and characterization of novel genes from legumes. Plant Physiol. 135:1179-1197.

Hirsch, A. M., and Fang, Y. 1994. Plant hormones and nodulation: What's the connection? Plant Mol. Biol. 26:5-9.

Hohnjec, N., Vieweg, M. F., Pühler, A., Becker, A., and Küster, H. 2005. Overlaps in the transcriptional profiles of Medicago truncatula roots inoculated with two different Glomus fungi provide insights into the genetic program activated during arbuscular mycorrhiza. Plant Physiol. 137:1283-1301.

Journet, E. P., El-Gachtouli, N., Vernoud, V., de Billy, F., Pichon, M., Dedieu, A., Arnould, C., Morandi, D., Barker, D. G., and GianinazziPearson, V. 2001. Medicago truncatula ENOD11: A novel RPRP-encoding early nodulin gene expressed during mycorrhization in arbuscule-containing cells. Mol. Plant-Microbe Interact. 14:737-748.

Kuppusamy, K. T., Endre, G., Prabhu, R., Penmetsa, R. V., Veereshlingam, H., Cook, D. R., Dickstein, R., and Vandenbosch, K. A. 2004. LIN, a Medicago truncatula gene required for nodule differentiation and persistence of rhizobial infections. Plant Physiol. 136:3682-3691.

Küster, H., Hohnjec, N., Krajinski, F., El, Y. F., Manthey, K., Gouzy, J., Dondrup, M., Meyer, F., Kalinowski, J., Brechenmacher, L., van Tuinen, D., Gianinazzi-Pearson, V., Pühler, A., Gamas, P., and Becker, A. 2004. Construction and validation of cDNA-based Mt6k-RIT macroand microarrays to explore root endosymbioses in the model legume Medicago truncatula. J. Biotechnol. 108:95-113.

Liang, Y., Mitchell, D. M., and Harris, J. M. 2007. Abscisic acid rescues the root meristem defects of the Medicago truncatula latd mutant. Dev. Biol. 304:297-307.

Limpens, E., Franken, C., Smit, P., Willemse, J., Bisseling, T., and Geurts, R. 2003. LysM domain receptor kinases regulating rhizobial Nod factor-induced infection. Science 302:630-633.

Limpens, E., Mirabella, R., Fedorova, E., Franken, C., Franssen, H., Bisseling, T. and Geurts, R 2005. Formation of organelle-like N2-fixing symbiosomes in legume root nodules is controlled by DMI2. Proc. Natl. Acad. Sci. U.S.A. 102:10375-10380.

Manthey, K., Krajinski, F., Hohnjec, N., Firnhaber, C., Pühler, A., Perlick, A. M., and Küster, H. 2004. Transcriptome profiling in root nodules and arbuscular mycorrhiza identifies a collection of novel genes induced during Medicago truncatula root endosymbioses. Mol. Plant-Microbe Interact. 17:1063-1077.

Matsubayashi, Y., and Sakagami, Y. 2006. Peptide hormones in plants. Annu. Rev. Plant Biol. 57:649-674.

Mergaert, P., Nikovics, K., Kelemen, Z., Maunoury, N., Vaubert, D., Kondorosi, A., and Kondorosi, E. 2003. A novel family in Medicago truncatula consisting of more than 300 nodule-specific genes coding for small, secreted polypeptides with conserved cysteine motifs. Plant Physiol. 132:161-173.

Middleton, P. H., Jakab, J., Penmetsa, R. V., Starker, C. G., Doll, J., Kalo, P., Prabhu, R., Marsh, J. F., Mitra, R. M., Kereszt, A., Dudas, B., Vandenbosch, K., Long, S. R., Cook, D. R., Kiss, G. B., and Oldroyd, G. E. 2007. An ERF transcription factor in Medicago truncatula that is essential for nod factor signal transduction. Plant Cell 19:1221-1234.

Mitra, R. M., Shaw, S. L., and Long, S. R. 2004. Six nonnodulating plant mutants defective for Nod factor-induced transcriptional changes associated with the legume-rhizobia symbiosis. Proc. Natl. Acad. Sci. U.S.A. 101:10217-10222.

Mulder, L., Hogg, B., Bersoult, A., and Cullimore J. V. 2005. Integration of signaling pathways in the establishment of the legume-rhizobia symbiosis. Physiol. Plant. 123:207-218.

Narita, N. N., Moore, S., Horiguchi, G., Kubo, M., Demura, T., Fukuda, H., Goodrich, J., and Tsukaya, H. 2004. Over-expression of a novel small peptide ROTUNDIFOLIA4 decreases cell proliferation and alters leaf shape in Arabidopsis thaliana. Plant J. 38:699-713.

Niwa, S., Kawaguchi, M., Imazumi-Anraku, H., Chechetka, S. A., Ishizaka, M., Ikuta, A., and Kouchi, H. 2001. Responses of a model legume Lotus japonicus to lipochitin oligosaccharide nodulation factors purified from Mesorhizobium loti JRL501. Mol. Plant-Microbe Interact. 14:848-856.

Oelkers, K., Goffard N., Weiller G. F., Gresshoff, P. M., Mathesius, U., 
and Frickey, T. 2008. Bioinformatic analysis of the CLE signaling peptide family. BMC Plant Biol. 8:1.

Oldroyd, G. E. 2007. Plant science. Nodules and hormones. Science 315:52-53.

Oldroyd, G. E., and Downie, J. A. 2004. Calcium, kinases and nodulation signalling in legumes. Nat. Rev. Mol. Cell Biol. 5:566-576.

Oldroyd, G. E., Engstrom, E. M., and Long, S. R. 2001. Ethylene inhibits the Nod factor signal transduction pathway of Medicago truncatula. Plant Cell 13:1835-1849.

Olsen, A. N., Mundy, J., and Skriver, K. 2002. Peptomics, identification of novel cationic Arabidopsis peptides with conserved sequence motifs. In Silico Biol. 2:441-451.

Pearce, G., Moura, D. S., Stratmann, J., and Ryan, C. A 2001. RALF, a 5$\mathrm{kDa}$ ubiquitous polypeptide in plants, arrests root growth and development. Proc. Natl. Acad. Sci. U.S.A. 98:12843-12847.

Penmetsa, R. V., and Cook, D. R. 1997. A legume ethylene-insensitive mutant hyperinfected by its rhizobial symbiont. Science 275:527-530.

Penmetsa, R. V., Frugoli, J. A., Smith, L. S., Long, S. R., and Cook, D. R. 2003. Dual genetic pathways controlling nodule number in Medicago truncatula. Plant Physiol. 131:998-1008.

Rohrig, H., Schmidt, J., Miklashevichs, E., Schell, J., and John, M. 2002. Soybean ENOD40 encodes two peptides that bind to sucrose synthase. Proc. Natl. Acad. Sci. U.S.A. 99:1915-1920.

Ryan C. A., Pearce G., Scheer J., and Moura, D. S. 2002. Polypeptide hormones. Plant Cell (Suppl.) 14:S251-264.

Sagan, M., Morandi D., Tarenghi, E., and Duc, G. 1995. Selection of nodulation and mycorrhizal mutants in the model plant Medicago truncatula (Gaertn.) after g-ray mutagenesis. Plant Sci. 111:63-71.

Sagan, M., de Larambergue, H., and Morandi, D. 1998. Genetic analysis of symbiosis mutants in Medicago truncatula. Pages 317-318 in: Biological Nitrogen Fixation for the 21st Century. C. Elmerich, A. Kondorosi, and W. E. Newton, eds. Kluwer Academic Publishers, Dordrecht, The Netherlands.

Scheer, J. M., Pearce, G., and Ryan, C. A. 2005. LeRALF a plant peptide that regulates root growth and development, specifically binds to 25 and $120 \mathrm{kDa}$ cell surface membrane proteins of Lycopersicon peruvianum. Planta 221:667-674.

Schnabel, E., Journet, E. P., de Carvalho-Niebel, F., Duc, G., and Frugoli, J. 2005. The Medicago truncatula SUNN gene encodes a CLV1-like leucine-rich repeat receptor kinase that regulates nodule number and root length. Plant Mol. Biol. 58:809-822.

Silverstein, K. A. T., Moskal, W. A., Wu, H. C., Underwood, B. A., Graham, M. A., Town, C. T., and VandenBosch, K. A. 2007. Small cysteine-rich peptides resembling antimicrobial peptides have been under-predicted in plants. Plant J. 51:262-280.
Stacey, G., Libault, M., Brechenmacher, L., Wan, J., and May, G. D. 2006. Genetics and functional genomics of legume nodulation. Curr. Opin. Plant Biol. 9:110-121.

Sun, J., Cardoza, V., Mitchell, D. M., Bright, L., Oldroyd, G., and Harris, J. M. 2006. Crosstalk between jasmonic aciD, ethylene and Nod factor signaling allows integration of diverse inputs for regulation of nodulation. Plant J. 46:961-970.

Timmers, A. C., Auriac, M. C., and Truchet, G. 1999. Refined analysis of early symbiotic steps of the Rhizobium-Medicago interaction in relationship with microtubular cytoskeleton rearrangements. Development 126:3617-3628.

Truchet, G., Roche, P., Lerouge, P., Vasse, J., Camut, S., de Billy, F., Prome, J. C., and Dénarié, J. 1991. Sulfated lipo-oligosaccharide signals of Rhizobium melilotielicit root nodule organogenesis in alfalfa. Nature 351:670-673.

van Brussel, A. A. N., Bakhuizen, R., van Spronsen, P. C., Spaink, H. P., Tak, T., Lugtenberg, B. J. J., and Kijne, J. W. 1992. Induction of preinfection thread structures in the leguminous host plant by mitogenic lipo-oligosaccharides of Rhizobium. Science 257:70-72.

van de Sande, K., Pawlowski, K., Czaja, I., Wieneke, U., Schell, J., Schmidt, J., Walden, R., Matvienko, M., Wellink, J., van Kammen, A., Franssen, H., and Bisseling, T. 1996. Modification of phytohormone response by a peptide encoded by ENOD40 of legumes and a nonlegume. Science 273:370-373

Veereshlingam, H., Haynes, J. G., Penmetsa, R. V., Cook, D. R., Sherrier, D. J., and Dickstein, R. 2004. nip, a symbiotic Medicago truncatula mutant that forms root nodules with aberrant infection threads and plant defense-like response. Plant Physiol. 136:3692-3702.

Wen, J., Lease K. A., and Walker, J. C. 2004. DVL, a novel class of small polypeptides: Over-expression alters Arabidopsis development. Plant J. 37:668-677.

Wu, J., Kurten, E. L., Monshausen, G., Hummel, G. M., Gilroy, S., and Baldwin, I. T. 2007. NaRALF, a peptide signal essential for the regulation of root hair tip apoplastic $\mathrm{pH}$ in Nicotiana attenuata, is required for root hair development and plant growth in native soils. Plant J. 52:877890.

\section{AUTHOR-RECOMMENDED INTERNET RESOURCES}

European Bioinformatics Institute website: www.ebi.ac.uk/microarrayexpress

The Institute for Genomic Research website: www.tigr.org

Medicago EST Navigation System (MENS) database: medicago.toulouse.inra.fr/Mt/EST 